\title{
INDONESIAN DEATH PENALTY: SEEN FROM THE CONCEPT BASED ON HUMAN RIGHTS
}

\author{
${ }^{1}$ Muhammad Andy Hakim, ${ }^{2}$ Joko Setiyono \\ ${ }^{1}$ Faculty of Law, Universitas Diponegoro, muhammadandyhakim1996@gmail.com \\ ${ }^{2}$ Faculty of Law, Universitas Diponegoro, jokosetiyono1961@gmail.com
}

\begin{abstract}
In the case of death penalty, Indonesia is a retentionist state of death penalty. It is evidenced through the regulation such as The Act Number 35 year 2009 on narcotics, The Act Number 1 year 1946 on criminal law regulation, The Act Number 31 year 1999 Jo The Act number 20 year 2001 about corruption and so on. Although Indonesia belongs to a retentionist country against death penalty, in the implementation remains in accordance with human rights. It was evidenced by ratifying international treaties relating to human rights and having legislation on human rights.
\end{abstract}

Keywords: Death Penalty; Concept; Human Rights

\section{Introduction}

The nature of human rights and the sheer fundamental for human benefit alone, it means that every human/individual can enjoy its human rights. Man is a whole person and in a society insoluble/not lost his identity/personality as a human, he has a right to himself loose from others. Human rights are an absolute right of human rights, even if the human rights of others are limited by other human rights. Human rights essentially guarantee the most fundamental rights of all human rights, namely the right of life. ${ }^{1}$

Death penalty is one of "the oldest criminal types" in its age, "as the age of human life" and "the most controversial of all criminal systems", both in the anglosaxon countries with the common law system, as well as in European countries with civil law tradition. The historical search for the death penalty has proved that nowadays, in countries in different parts of the world is always in dispute the application of the death penalty. ${ }^{2}$

The death penalty is one of the criminally found in "The Indonesian Penal Code". The death penalty is one of the penal forms. A penal is a mourning or suffering that is deliberately inflicted upon a person doing a deed that meets "certain conditions". A certain condition of deed is "the deed of the person who allows the granting of penal".

\footnotetext{
Umar Anwar, "Penjatuhan Hukuman Mati Bagi Bandar Narkoba Ditinjau Dari Aspek Hak Asasi Manusia ( Analisa Kasus Hukuman Mati Terpidana Kasus Bandar Narkoba ; ( Case Analyses on the Death Penalty of Drugs Dealer ; Freddy Budiman ))," Jurnal Legislasi Indonesia 13, no. 3 (2016): 241-52.

2 Auliah Andika Rukman, "Pidana Mati Ditinjau Dari Prespektif Sosiologis Dan Penegakan HAM," Jurnal Equilibrium Pendidikan Sosiologi IV, no. 1 (2016): 1-10, https://doi.org/10.1002/hlca.19770600336.
} 
The death penalty is a matter of active controversy in different countries. Among countries around the world are almost all countries in "Europe" and many countries in "Asia Pacific" (Australia, New Zealand, and East Timor) and Canada have eliminated the death penalty. All countries in "Europe" and many countries in "Asia Pasific" (Australia, New Zealand, and East Timor) and Canada rejects death penalty because they are abolisinist country. ${ }^{3}$ They do not want to apply the death penalty in their country with some considerations such as execution arising from injustice cannot be changed; wrong in sentenced, innocent people have received the death penalty, and tragically, killed by the state, and so on. The abolisionist consider that the death penalty is the most important type of human rights violation, which is the right to life. This fundamental right is the kind of right that cannot be violated, reduced, or restricted under any circumstances, be it in an emergency, a war, including when a person becomes an inmate. ${ }^{4}$

The death penalty is the allotment of punishment that is currently disputed by "jurists and criminologists", as it sees the consequences inflicted by the death sentence itself, which is mortality. Cesare Beccaria in the decade of 1780 's had opposed this type of sanction because it was considered inhuman and ineffective. ${ }^{5}$

Death penalty began to applied in Indonesia since 1 January 1918 as found in "'Wetboek Van Strafrecht" set by The Dutch Colonial Government based on "K.B.v. October 15, 1915, 33. S. 15-732 JIS. 17-497, 645", has been enforced in The Dutch East Indies. The provision has been transformed in explanatory memory "Memorie van Toelichting", further in The Act Number 1 year 1946 on the criminal law regulation. The State is entitled to carry out all of these rules, including the death penalty in order that the country may fulfill its obligations to safeguard Law and public interest in society, ${ }^{6}$ from that moment, Indonesia is a country that defend (retensionist) the death penalty to the present.

Based on the explanation above, in this occasion and this paper, the author wants to discuss about Indonesian death penalty : seen from the concept based on human rights.

3 Masoud Ahmad, "Worldwide Debate to Abolish the Death Penalty Forever," International Journal of African and Asian Studies 14 (2015): 139-53.

4 Saharuddin Daming, "Konfigurasi Pertarungan Abolisionisme Versus Retensionisme Dalam Diskursus Keberadaan Lembaga Pidana Mati Di Tingkat Global Dan Nasional," Jurnal Yustisi Vol. 3 No. 1 Maret 3, no. 1 (2016): 36-77.

5 FERAWATI, “Kajian Hukum Dan Ham Terhadap Penjatuhan Pidana Mati Bagi Terpidana Narkotika,” Jurnal Ilmu Hukum 4, no. 3 (2015): 138-52.

6 Auliah Andika Rukman, "Pidana Mati Ditinjau Dari Prespektif Sosiologis Dan Penegakan HAM." 


\section{Methods}

This research method is normative. Normative legal research is a literature research that is research on secondary data. Secondary data in the legal field can be distinguished from the primary legal material, secondary legal material and tertiary legal materials. In this research writing, authors use primary legal materials and secondary legal materials. The primary law materials and secondary legal materials play an important role. Researchers use primary legal material such as Ratification Act on the ICCPR "International Convenants On Civil And Political Rights", Constitution of the Republic Indonesia 1945, Indonesian Penal Code, The Act Number 39 year 1999 on Human rights and so on. Besides researchers using primary legal material, researchers also use secondary legal materials such as book and journals. The diversity of knowledge from legislation, book and journals, both national journals and international journals has helped researchers to achieve reliable conclusions and contributing recommendations.

\section{Results And Discussion}

\subsection{Death Penalty Seen From Human Rights}

Death penalty sanction is a penalty that is carried out by depriving one's soul in violation of the provisions of the law. This death penalty is also "the oldest" and "the most controversial" sanction of various other sanction. ${ }^{7}$

Human rights are the basic right that is brought by human from birth as the grace of Almighty God, then the human rights are not sourced from the state of law, but merely to be based on God as the creator of the universe and its contents, so that The human rights cannot be reduced "Non Derogable Rights". 8

Indonesia has begun to incorporate human rights into the constitution such as Constitution of the Republic Indonesia 1945, The Act Number 39 Year 1999 on Human Rights, Ratification Act on the ICCPR “International Convenants On Civil And Political Rights”, and so on. In the Constitution of the Republic Indonesia after the amendment in "article $28 A$ " is mentioned:

Roni Efendi, "PIDANA MATI DALAM PERSPEKTIF HUKUM PIDANA DAN HUKUM PIDANA ISLAM,” Jurnal Ilmiah Syariah 16, no. 1 (2017): 125-42.

8 Bagir Manan, Perkembangan Pemikiran Dan Pengaturan Hak Asai Manusia Di Indonesia (Jakarta: Yayasan Hak Asasi Manusia, Demokrasi dan Supermasi Hukum, 2001). 
"Everyone has the right to live and be entitled to defend his life and lives." The right to live and sustain life and life "article $28 A$ " is similar to the content of article 3 of the UN DUHAM. ${ }^{9}$

According to article 9 (1) The Act Number 39 Year 1999: "Everyone has the right to life, sustain life, and improve his or her life. The right to life is even in the newborns or people who are convicted of death. In the event of an extraordinary condition that is for the sake of his mother's life in the case of abortion or by a court ruling in a criminal case, the act of abortion or criminal death in the case and/or condition may still be permitted. Only on these two things is the right to life can be limited", ${ }^{10}$ it complies with to article 5 of "The Universal Declaration of Human Rights", which reads: ${ }^{11}$ "No one can be tortured or treated or punished vicious, inhuman, or degrading". While article 8 reads, :"Everyone is entitled to an effective solution by the national judiciary to obtain the same protection against actions that violate the fundamental rights granted to them by the Constitution or by Law ", the UN also issued a guide titled "Safeguards Guaranteeing Protection of the Rights of Those Facing the Death Penalty".

Human rights concepts are also contained in Ratification Act on the ICCPR "International Convenants On Civil And Political Rights" in the form of restrictions the death penalty. It is in the article $6:^{12}$ 1) Every human being is entitled to the right to life attached to it. This right is necessary to be protected by law. No one can arbitrarily revoke his life rights; 2) In a country that has not eliminated the death penalty, the death penalty ruling can only be dropped against some of the most serious crimes in accordance with the law prevailing at the time of crime, and does not contradict the provisions on the prevention and Law of genocide. This penalty can only be done on the basis of the final decision imposed by the Court of competent jurisdiction; 3) If life deficiency is a crime of genocide, it must be understood that there is nothing in this article the authority of the state that is a party to whisting, to reduce the obligations that have been imposed by the provisions in the Convention prevention and Punishment for genocide crimes; 4) Any person who has been sentenced to death is entitled to request forgiveness or reimbursement of punishment. Amnesty, forgiveness or the replacement of the death penalty can be given in all cases; 5) The death penalty will not be imposed on crimes committed by a person under the age

\footnotetext{
9 Amelia Arief, "PROBLEMATIKA PENJATUHAN HUKUMAN PIDANA MATI DALAM PERSPEKTIF HAK ASASI MANUSIA DAN HUKUM PIDANA," Jurnal Kosmik Hukum 19, no. 1 (2019): 91-108.

10 The Act Number 39 Year 1999 on Human Rights.

11 Umar Anwar, "Penjatuhan Hukuman Mati Bagi Bandar Narkoba Ditinjau Dari Aspek Hak Asasi Manusia ( Analisa Kasus Hukuman Mati Terpidana Kasus Bandar Narkoba; ( Case Analyses on the Death Penalty of Drugs Dealer ; Freddy Budiman ))."

12 Ratification Act on The International Covenant On Civil And Political Rights (International Convenants On Civil And Political Rights).
} 
of eighteen (18) years and will not be conducted against a pregnant woman; 6) Nothing in this article shall be used to suspend or prevent the elimination of the death penalty by the state that is party to this conventant.

Based on explanation above, this restriction is intended to prevent the ruler from using death penalty. Not all crimes were sentenced to death penalty, but only "serious crimes" can be sentenced to death penalty such ad drugs dealer, terrorism, and so on.

\subsection{The Rules Governing Death Penalty in Indonesia}

In general, the death penalty applied in Indonesia is based on the laws and regulations applicable in Indonesia because Indonesia is one of the countries that defend (retentionist) the death penalty both "de jure" and "de facto". 13

The death penalty is an attempt to criminalize, intended to criminalize perpetrators and frighten potential perpetrators. The effort is the influence of the application of the basic theory of absolute funding and classical funding flow that is still applied in Indonesia. In addition to the application ofjeraan, Indonesia's criminal justice system adheres to the basic theory of relative funding and modern funding flows, by implementing measures and recovery of damaged situations as a result of criminal acts. ${ }^{14}$

The rules in Indonesia regulating the death penalty :

\section{A. Death Penalty in The Indonesian Penal Code}

In The Indonesia Penal Code, the criminal type in article 10. According to article 10 Indonesian Criminal Code, criminal types are: a) Criminal Principal: 1) Death penalty, 2) Jail criminal, 3) Criminal confinement, 4) Criminal penalties (fines); and b) Additional criminal: 1) Revocation of certain rights, 2) Seizement of certain goods (Confiscation of certain items), 3) Announcement of Judge ruling.

The death penalty is in the article:" "Article 104; Article 111 paragraph 2; Article 124 paragraph 3; Article 140 paragraph 3; Article 340; Article 365 paragraph 4; Article 368 paragraph 2; Article 444".

13 M.Rizal, "PENERAPAN HUKUMAN PIDANA MATI PERSPEKTIF HUKUM ISLAM DI INDONESIA M. Rizal,"Jurnal Nurani 15, no. 1 (2015): 101-16.

14 Warih Anjari, "Penjatuhan Pidana Mati Di Indonesia Dalam Perspektif Hak Asasi Manusia," Jurnal Widya Yustisia 1, no. 2 (2015): 107-15.

15 Iin Mutmainnah, "Pidana Mati Terhadap Pelaku Kejahatan Berat Dan Menyengsarakan," Jurnal Al-Qadāu 2 (2015): 209-21. 
Based on the explanation above, the authors can analyze that in Indonesia Penal Code, the death penalty can be threatened on: ${ }^{16}$ 1) Makar against the head of government and the vice head of government; 2) Persuading a foreign country for hostile or war, if the hostility was done or so war; 3) Help enemy in War; 4) Makar against the king or head of the companions who are planned and deadly; 5) Murder planning; 6) Theft with violence resulting in severe or dead injuries; 7) Extortion with violence resulting in severe or dead wounds; and 8) Piracy at sea, coastal and river resulting in death.

The death penalty can be given by the judge after committing consideration based on the legal fact at the trial and sufficient evidence so that the judge can decide someone to get one of these forms of punishment. ${ }^{17}$

\section{B. Death Penalty Outside The Indonesian Penal Code}

In outside The Indonesian Penal Code is regulated as "a special laws", i.e: ${ }^{18}$ 1) The criminal acts of firearms, ammunition, or any explosives set in article 1 paragraph (1) of The Act Number 12/DRT/1951; 2) The economic criminal act in article 1 paragraph (2) Regulation of substitute legislation Number 21 year 1959 concerning the threat of punishment of The Act Number 7/DRT/1955; 3) The criminal offence concerning the basic provisions of the atomic energy, namely in article 23 of The Act Number 31 year 1964;4) The criminal acts of drug and psychotropic, death penalty sanctions in The Act Number 35 year 2009 on narcotics in some chapters, i.e : “Article 113 paragraph (2); Article 114 paragraph (2); Article 118 paragraph (2); Article 119 paragraph (2); Article 121 paragraph (2)". In The Act Number 5 year 1997 on psychotropic, death penalty is governed in article 59 paragraph (2); 5) The corruption Act is located in article 2 paragraph (2) of The Act Number 31 year 1999 Jo The Act Number 20 year 2001 ; 6) The criminal offence against human rights in The Act Number 26 year 2000 is found in chapters 36 and 37; and 7) The Criminal acts of terrorism in The Act Number 1 year 2002, death penalty is governed in several chapters, for example article 6 to article 10.

Legal irregularities need to be applied in criminal justice proceedings. Because in the process or a judicial mechanism facing an extraordinary criminal offense aspect of the evidence

16 Ibid.

17 Umar Anwar, "Penjatuhan Hukuman Mati Bagi Bandar Narkoba Ditinjau Dari Aspek Hak Asasi Manusia ( Analisa Kasus Hukuman Mati Terpidana Kasus Bandar Narkoba; ( Case Analyses on the Death Penalty of Drugs Dealer ; Freddy Budiman )).”

18 Rosa Kumalasari, “Kebijakan Pidana Mati Dalam Perspektif Ham,” Jurnal Literasi Hukum 2, no. 1 (2018): 114. 
is very difficult. Operandi mode of the culprit is sophisticated, their network is extensive as well as very confidential and involve organized networks like cyber space virtual worlds. To detect and pursue the perpetrators difficult for the perpetrators of crimes in the extra ordinary crimes deserve to be sentenced to death. ${ }^{19}$

\subsection{Some Obstacles in The Imposition of Death Penalty in Indonesia}

Death penalty in positive law as long as it is one of the main criminal. However, in the formulation policy during this time, criminal death has never been formulated in a singular "imperative/absolute", but it is always formulated with "alternative types of criminal types" and only for "certain delics". Thus, even though criminal death is subject to criminal, the fact is that it is "a particular fundamental criminal and is always put into an alternative". With such an alternative formulation, the death criminal is viewed as the last alternative or "last resort" in protecting the community.

Indonesia as "a retentionist" state against the death penalty, such conditions make the law enforcement officers work hard to gain "public sympathy" and support to be able to put on a death penalty appropriately. Thus, law enforcement officers can maximize efforts to prevent public order disruptions and peace within the community. ${ }^{20}$

Based on the explanation above, sometimes death penalty is not imposed appropriately. In certain criminal acts, death penalty has not been fully applied. ${ }^{21}$ Indonesia through the law enforcement officials continue to socialize the community in order not to commit acts that could be threatened by death penalty, it is a preventive effort. According to G. Pieter Hoefnagels, crime prevention efforts can be pursued in a variety of ways, ie : "the application of Criminal law", "prevention without penalty", "affect people's view of crime and punishment through the media". Criminal prevention efforts can be achieved by : "punishment" (Criminal Law) and "nonpunishment" (other than criminal law). ${ }^{22}$

19 I Made Pasek Budiawan, "KONSEPSI DAN APLIKASI PIDANA MATI DALAM PERADILAN DI INDONESIA,” Jurnal Magister Hukum Udayana (Udayana Master Law Journal) 5, no. 4 (2016): 711-27.

20 Joko Setiyono, "Human Rights Based Law Enforcement for the Violation of Local Regulation By Civil Service Police of Semarang Municipality," Jurnal Diponegoro Law Review 1, no. 1 (2016): 61, https://doi.org/10.14710/dilrev.1.1.2016.61-80.

21 Piers Gooding and Charles O'Mahony, "Laws on Unfitness to Stand Trial and the UN Convention on the Rights of Persons with Disabilities: Comparing Reform in England, Wales, Northern Ireland and Australia," International Journal of Law, Crime and Justice 44 (2016): 122-45, https://doi.org/10.1016/j.ijlcj.2015.07.002.

22 Dyah Listyarini, "Juvenile Justice System Through Diversion and Restorative Justice Policy," Jurnal Diponegoro Law Review 2, no. 1 (2017): 168, https://doi.org/10.14710/dilrev.2.1.2017.168-184. 
As we know, death penalty should be threatened against "serious crimes", such as narcotics, terrorism and so on. Therefore, "for a mild crime", the death penalty should not be dropped. Mild crimes such as mild theft (due to hunger), do not be threatened with death penalty but with other sanction.

\subsection{Retentionist and Abolitionist Opinions on Death Penalty}

Retentionist is a designation for people who "still retain the death penalty in their country", abolitionist is a designation for people who "have eliminated the death penalty in their country". In this world there are several countries that retentionist and who are abolitionist. The following are the opinions of retentionist and abolitionist.

The retentionist's opinion to keep death penalty are: ${ }^{23}$ 1) Destroying the murderer through the execution of death is "a fair retribution" and rescues victims of "future trauma"; 2) Penalties must conform to the severity of the breach and the worst crime must be severely punished; 3 ) The right to the life of the person who commits murder, must be lost; 4) This gives peace of mind to many of the victims of crime and their families; 5) Death penalty is "the most effective way" to protect people from criminals; 6) Death penalty is retaliatory only because the criminals must suffer in the same way as their victims do; 7) This shows how serious the community sees the most cruel crimes. Society must make a deterrent against evil. The death penalty serves as an effective deterrent; 8) It supports Democratic people; 9) Death is a fair punishment and the death penalty has been lawfully applied in the Constitution; and 10) Death penalty can reduce criminals and prevent others from committing serious crimes.

The abolisinist's opinion to reject death penalty are: ${ }^{24}$ 1) Death is "a cruel and unusual punishment"; 2) The death penalty is applied "arbitrarily" and "inconsistently"; 3) A rehabilitated criminal can make a morally valuable contribution to society; 4) Execution arising from injustice cannot be changed; 5) The death penalty is "a brutal retaliation" against the people who tolerate it; 6) The death sentence is "irrevocable" and must be avoided in order to avoid the wrong sentence in the court; 7) The death penalty is used "disproportionately" against poor people, who cannot afford expensive legal counsel, as well as racial, ethnic and religious minorities; 8) Wrong in sentenced, innocent people have received the death penalty, and tragically, killed by the state; 9) Fear of the death sentence never diminishes evil. Through most historical executions are public and brutal. Some criminals were even destroyed to death slowly

23 Ahmad Masoud, "Worldwide Debate to Abolish the Death Penalty Forever."

24 Ibid. 
under heavy loads. Crime is more common at that time than it is now. Evidence suggests that execution does not act as a deterrent to death penalty; and 10) The motive for capital punishment might be "revenge". Legal retaliation supports social solidarity with lawbreakers and represents an alternative to personal revenge from those who are harmed.

\section{Conclusions}

Based on the explanation above, it can be concluded that : 1) Death Penalty In The Indonesian Penal Code. In The Indonesia Penal Code, the criminal type in article 10. According to article 10 Indonesian Criminal Code, criminal types are: a) Criminal Principal: Death penalty, Jail criminal, Criminal confinement, and Criminal penalties (fines); b) Additional criminal: Revocation of certain rights, Seizement of certain goods (Confiscation of certain items), and Announcement of Judge ruling.

The death penalty is in the article: "Article 104; Article 111 paragraph 2; Article 124 paragraph 3; Article 140 paragraph 3; Article 340; Article 365 paragraph 4; Article 368 paragraph 2; Article 444".

Based on the explanation above, the authors can analyze that in Indonesia Penal Code, the death penalty can be threatened on: 1) Makar against the head of government and the vice head of government; 2) Persuading a foreign country for hostile or war, if the hostility was done or so war; 3) Help enemy in War; 4) Makar against the king or head of the companions who are planned and deadly; 5) Murder planning; 6) Theft with violence resulting in severe or dead injuries; 7) Extortion with violence resulting in severe or dead wounds; 8) Piracy at sea, coastal and river resulting in death.

The death penalty can be given by the judge after committing consideration based on the legal fact at the trial and sufficient evidence so that the judge can decide someone to get one of these forms of punishment.

2) Death Penalty Outside The Indonesian Penal Code. In outside The Indonesian Penal Code is regulated as "a special laws", i.e: 1) The criminal acts of firearms, ammunition, or any explosives set in article 1 paragraph (1) of The Act Number 12/DRT/1951;2) The economic criminal act in article 1 paragraph (2) Regulation of substitute legislation Number 21 year 1959 concerning the threat of punishment of The Act Number 7/DRT/1955; 3) The criminal offence concerning the basic provisions of the atomic energy, namely in article 23 of The Act Number 31 year 1964; 4) The criminal acts of drug and psychotropic, death penalty sanctions in The Act 
Number 35 year 2009 on narcotics in some chapters, i.e : "Article 113 paragraph (2); Article 114 paragraph (2); Article 118 paragraph (2); Article 119 paragraph (2); Article 121 paragraph (2)". In The Act Number 5 year 1997 on psychotropic, death penalty is governed in article 59 paragraph (2); 5) The corruption Act is located in article 2 paragraph (2) of The Act Number 31 year 1999 Jo The Act Number 20 year 2001; 6) The criminal offence against human rights in The Act Number 26 year 2000 is found in chapters 36 and 37; and 7) The Criminal acts of terrorism in The Act Number 1 year 2002, death penalty is governed in several chapters, for example article 6 to article 10 .

The death penalty has a negative and positive side when seen from "retentionist" and "abolitionist" views. According to the conclusion that the authors get from the overall opinion of retentionist, that they still retain the death penalty for use in severe and "serious crimes" such as narcotics, terorism, and so on. This crime is often referred to as "the extra ordinary crimes" which is a crime that has a great danger to the nation, state and society. Conversely, for abolitionist, the conclusion that the authors get of all their opinions, that abolitionist "respects the right of life of every human being".

The position of the death penalty in the principles of law and justice in Indonesia is very strong and entrenched. Because until now our legal system provided the death penalty as part of the existing funding system. Even the death penalty in the principle of justice is seen as a means of balance and restoration of the dignity of nations and communities tainted by rampant crime rates that have such implications in society. The death penalty is a means of tackling crime. The selection of penal means in tackling crime to get the deterrent effect for the community and against the convicted themselves so as not to commit criminal acts again.

The position of the death penalty in the principle of freedom and religious values, especially in Indonesia in general, is very accommodating. None of the religious teachings that are majority embraced in Indonesia reject the death penalty. Even the enactment of the death penalty is actually a manifestation of human rights obligations and justice justified by law. Through the death penalty, the general prevention of the effects of entangletion, it is expected that the crime rate can decrease.

The relationship between human rights and death penalty in this paper is although this is a country that maintains the death penalty, in its implementation it continues "to pay attention" to human rights. The human rights function here is "to control the use of the death penalty to be precise and not used recklessly". 


\section{Acknowledgement}

This research did not receive any specific grant from funding agencies in the public, commercial, or non-profit sectors.

\section{References}

Ahmad, Masoud. "Worldwide Debate to Abolish the Death Penalty Forever." International Journal of African and Asian Studies 14 (2015): 139-53.

Anjari, Warih. "Penjatuhan Pidana Mati Di Indonesia Dalam Perspektif Hak Asasi Manusia." Jurnal Widya Yustisia 1, no. 2 (2015): 107-15.

Anwar, Umar. "Penjatuhan Hukuman Mati Bagi Bandar Narkoba Ditinjau Dari Aspek Hak Asasi Manusia ( Analisa Kasus Hukuman Mati Terpidana Kasus Bandar Narkoba; ( Case Analyses on the Death Penalty of Drugs Dealer; Freddy Budiman ))." Jurnal Legislasi Indonesia 13, no. 3 (2016): 241-52.

Arief, Amelia. "PROBLEMATIKA PENJATUHAN HUKUMAN PIDANA MATI DALAM PERSPEKTIF HAK ASASI MANUSIA DAN HUKUM PIDANA.” Jurnal Kosmik Hukum 19, no. 1 (2019): 91-108.

Budiawan, I Made Pasek. "KONSEPSI DAN APLIKASI PIDANA MATI DALAM PERADILAN DI INDONESIA.” Jurnal Magister Hukum Udayana (Udayana Master Law Journal) 5, no. 4 (2016): 711-27.

Efendi, Roni. "PIDANA MATI DALAM PERSPEKTIF HUKUM PIDANA DAN HUKUM PIDANA ISLAM.”Jurnal Ilmiah Syariah 16, no. 1 (2017): 125-42.

FERAWATI. "Kajian Hukum Dan Ham Terhadap Penjatuhan Pidana Mati Bagi Terpidana Narkotika.” Jurnal Ilmu Hukum 4, no. 3 (2015): 138-52.

Gooding, Piers, and Charles O'Mahony. "Laws on Unfitness to Stand Trial and the UN Convention on the Rights of Persons with Disabilities: Comparing Reform in England, Wales, Northern Ireland and Australia." International Journal of Law, Crime and Justice 44 (2016): 122-45. https://doi.org/10.1016/j.ijlcj.2015.07.002

Kumalasari, Rosa. "Kebijakan Pidana Mati Dalam Perspektif Ham.” Jurnal Literasi Hukum 2, no. 1 (2018): 1-14.

Listyarini, Dyah. "Juvenile Justice System Through Diversion and Restorative Justice Policy." Jurnal Diponegoro Law Review 2, no. 1 (2017): 168. https://doi.org/10.14710/dilrev.2.1.2017.168-184. 
M.Rizal. "PENERAPAN HUKUMAN PIDANA MATI PERSPEKTIF HUKUM ISLAM DI INDONESIA M. Rizal.” Jurnal Nurani 15, no. 1 (2015): 101-16.

Mutmainnah, Iin. "Pidana Mati Terhadap Pelaku Kejahatan Berat Dan Menyengsarakan.” Jurnal Al-Qadāu 2 (2015): 209-21.

Rukman, Auliah Andika. "Pidana Mati Ditinjau Dari Prespektif Sosiologis Dan Penegakan HAM." Jurnal Equilibrium Pendidikan Sosiologi IV, no. 1 (2016): 1-10. https://doi.org/10.1002/hlca.19770600336.

Saharuddin Daming. "Konfigurasi Pertarungan Abolisionisme Versus Retensionisme Dalam Diskursus Keberadaan Lembaga Pidana Mati Di Tingkat Global Dan Nasional.” Jurnal Yustisi Vol. 3 No. 1 Maret 3, no. 1 (2016): 36-77.

Setiyono, Joko. "Human Rights Based Law Enforcement for the Violation of Local Regulation By Civil Service Police of Semarang Municipality.” Jurnal Diponegoro Law Review 1, no. 1 (2016): 61. https://doi.org/10.14710/dilrev.1.1.2016.61-80.

Bagir Manan, Perkembangan Pemikiran Dan Pengaturan Hak Asai Manusia Di Indonesia (Jakarta: Yayasan Hak Asasi Manusia, Demokrasi dan Supermasi Hukum, 2001).

The Act Number 39 Year 1999 on Human Rights.

Indonesian Criminal Code

Ratification Act on The International Covenant On Civil And Political Rights (International Convenants On Civil And Political Rights). 